\title{
О ПРОДУКТИВНОСТИ РАКВЕРЕСКОГО ФОСФОРИТОНОСНОГО РАЙОНА
}

Под продуктивностью месторождения вообще подразумевается количество полезного компонента (в т, кг, г или в каратах) на единицу его площади. В рассматриваемом варианте продуктивность выражается в количестве фосфорного ангидрида $\left(\mathrm{P}_{2} \mathrm{O}_{5}\right)$ в тоннах, содержимого в фосфоритном пласте, на площади равной $1 \mathrm{~m}^{2}$.

В кондициях для месторождений фосфоритов Эстонской ССР, составленных в 60 -е годы В. М. Прокофьевым, приводился термин «метропроцент», как наиболее удачно выбранный для характеристики фосфоритов, имеющих мощность пласта меньше кондиционной, но с очень высоким содержанием $\mathrm{P}_{2} \mathrm{O}_{5}$. В дальнейшем во многих отчетах о геолого-поисковых и разведочных работах, проведенных на разных месторождениях фосфоритов Эстонии, приводились средние значения продуктивности фосфоритной руды по подсчетным блокам.

Совершенно новое содержание приобрело понятие «продуктивность фосфоритов» в 1980 г., когда геологами ГИГХС-а (Кингисеппского КНИЛ-а) на основе данных из Управления геологии ЭССР была дана характеристика продуктивности фосфоритов т. н. Раквереской площади (ныне Раквереское месторождение фосфоритов). Составлена карта продуктивности *, на которой показаны значения метропроцентов для каждой буровой скважины и проведены изолинии с целью показа изменчивости их по площади. Так как составленная карта является производной от двух карт - содержания $\mathrm{P}_{2} \mathrm{O}_{5}$ и мощности промышленного пласта, - она дает более полное представление о количестве полезного компонента в промпласте, чем каждая из этих двух карт в отдельности.

Расчеты значений продуктивности производились по формуле, дополненной автором:

$$
\mathrm{P}=\frac{\mathrm{M} \cdot \mathrm{C} \cdot \mathrm{O} \cdot \Pi}{100}
$$

где $\mathrm{P}$ - продуктивность $\left(\mathrm{P}_{2} \mathrm{O}_{5}, \mathrm{~T} / \mathrm{M}^{2}\right) ; \mathrm{M}$ - мощность промпласта, м; $\mathrm{C}$ - средневзвешенное содержание $\mathrm{P}_{2} \mathrm{O}_{5}$ в промпласте, \%; О - объемный вес фосфоритной руды (принимается равным $\left.2 \mathrm{~T} / \mathrm{M}^{3}\right)$; П - расчетная площадь (равняется $1 \mathrm{~m}^{2}$ ).

В настоящей статье приводится схема продуктивности всего Раквереского фосфоритоносного района (рисунок), из которой видно, что продуктивность детально разведанных месторождений Азери и Тоолсе

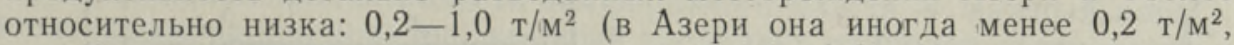
а в Тоолсе - лишь изредка превышает $\left.1,0 \mathrm{~T} / \mathrm{m}^{2}\right)$. На участках, рас* Загураев В. Г. и др. Геолого-геохимические исследования полезных ископаемых
района месторождения Тоолсе. Кннгисепп, 1980. (Рукопись в фондах ГИГХСа). 



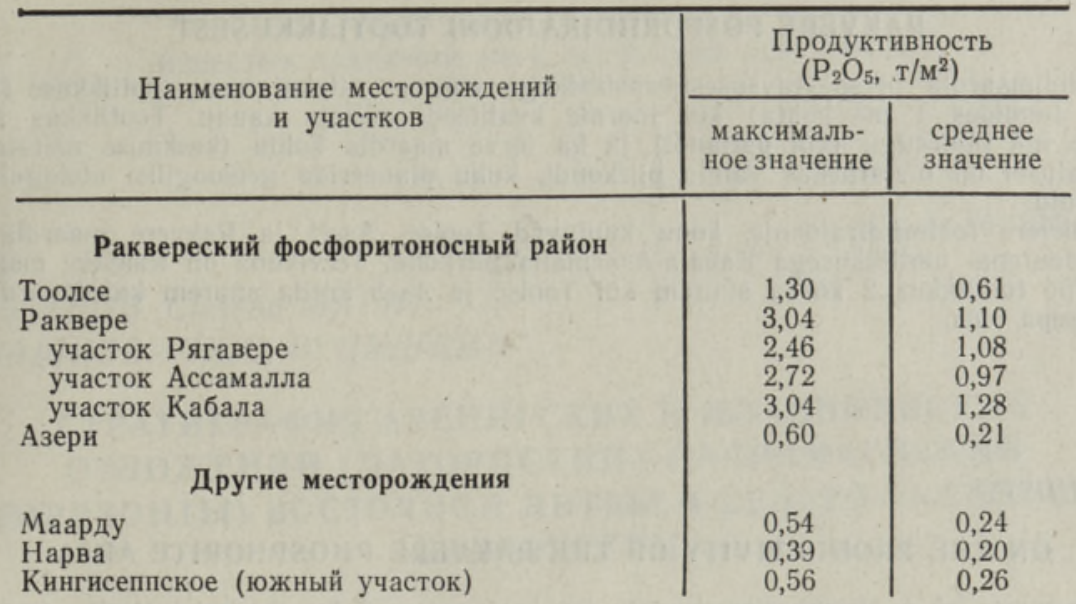

положенных западнее месторождения Тоолсе (Вихула) и между месторождениями Тоолсе и Азери (Виру-Нигула), продуктивность редко превышает $0,2 \mathrm{~T} / \mathrm{M}^{2}$.

Совершенно иная картина наблюдается в пределах Раквереского месторождения. На территории, прилегающей с юга к месторождению Тоолсе, продуктивность остается от $0,2-0,3$ до $0,8-0,9$ т/ $/ \mathrm{m}^{2}$. В южном направлении она постепенно возрастает, приобретая максимальные значения в полосе, протянувшейся от с. Кабала почти до с. Ассамалла. Названная полоса продуктивностью более 2 т/м² имеет СВ-ЮЗ направление, длина ее достигает порядка 20-25 км. В пределах названной зоны мощность фосфоритного пласта достигает 7-8 м и содержание в нем $\mathrm{P}_{2} \mathrm{O}_{5} 15-20 \%$. K югу и северу от названной зоны продуктивность приобретает наименьшее значение (ниже $0,5 \mathrm{~T} / \mathrm{m}^{2}$ ) в окрестностях пос. Сонда (в северо-восточной части месторождения), между пос. Кадрина и Раквере (в северо-западной части) и около пос. ВяйкеМаарья (в южной и юго-западной части).

Согласно временным кондициям, в пределах Раквереского месторождения минимально допустимые значения мощности промпласта и средневзвешенного содержания $\mathrm{P}_{2} \mathrm{O}_{5}$ по буровой скважине приняты соответственно равными 1,5 м и $6 \%$. Следовательно, даже при минимальных показателях руды продуктивность составляет около $0,2 \mathrm{~T} / \mathrm{M}^{2}$. По сравнению с другими месторождениями Прибалтийского фосфоритоносного бассейна продуктивность фосфоритов Раквереского месторождения заметно выше (таблица). Средняя продуктивность эксплуатируемых Маардуского и Кингисеппского месторождений почти одинакова (соответственно 0,24 и $0,26 \mathrm{~T} / \mathrm{M}^{2}$ ). Средняя продуктивность месторождения Тоолсе превышает эту величину более чем в 2 раза, а Раквереского - в 4-5 раз. Несмотря на большое значение продуктивности, имеются некоторые факторы (глубокое залегание пласта, высокая концентрация в руде вредных соединений и др.), которые значительно ухудшают качество фосфоритной руды Раквереского месторождения и осложняют условия планируемой его эксплуатации.

Тем не менее продуктивность фосфоритного пласта - важный показатель качества фосфоритов, который позволяет наиболее обоснованно выявлять участки, перспективные для постановки более детальных геологических работ, оперируя минимальным количеством карт. 20/VIII 1982 


\section{RAKVERE FOSFORIIDIRAJOONI TOOTLIKKUSEST}

Fosforiidimaardla perspektiivsusest saab kõige parema ettekujutuse tootlikkuse $\left(\mathrm{P}_{2} \mathrm{O}_{5}\right.$ kogus tonnides $1 \mathrm{~m}^{2}$ kohta) kui toorme kvaliteedi näitaja kaudu. Tootlikkus arvutatakse iga puuraugu (või paljandi) ja ka terve maardla kohta (keskmise näitajana). Selle alusel on otstarbekas valida piirkondi, kuhu planeerida geoloogilisi otsinguid ja uuringuid.

Rakvere fosforiidirajoonis, kuhu kuuluvad Toolse, Aseri ja Rakvere maardla, on kõige suurema tootlikkusega Kabala-Assamalla piirkond. Tervikuna on Rakvere maardla keskmine tootlikkus 2 korda suurem kui Toolse ja $4-5$ korda suurem kui Maardu ia Kingissepa oma.

\section{R. RAUDSEP}

\section{ON THE PRODUCTIVITY OF THE RAKVERE PHOSPHORITE AREA}

The prospects of a phosphorite deposit are best assessed by the productivity (amount of $\mathrm{P}_{2} \mathrm{O}_{5}$ in metric tons per $\mathrm{m}^{2}$ of area) as well as by the index of the quality of the mineral. The productivity is calculated for each borehole (or outcrop) as well as for the whole deposit (as a mean index). On that basis it is advisable to choose areas where to plan geological prospecting and research.

In the Rakvere phosphorite area, which includes the Toolse, Aseri and Rakvere deposits, the highest productivity has been stated in the Kabala-Assamalla district. As a whole, the average productivity of the Rakvere phosphorite deposit exceeds that of Toolse twice, and the productivity of the Maardu and Kingissepa deposits 4-5 times over. 